\title{
Sustainable Development and Humanization of Economic Growth: Environmental and Social Well-Being
}

\author{
Sergey Kovalevsky,*, Samer Khouri², Eyvaz Gasanov ${ }^{3}$, Anna Lozhnikova $^{4}$, and Maria \\ Konovalova $^{5}$ \\ ${ }^{1}$ T.F. Gorbachev Kuzbass State Technical University, 650000 Kemerovo, 28 Vesennya st., \\ Kemerovo, Russia \\ ${ }^{2}$ Technical University Košice, Faculty BERG, Letná 9, 04001 Košice, Slovakia \\ ${ }^{3}$ Khabarovsk State University of Economy and Law, Economics Department of International \\ Economic Relations Faculty, 680042134 Tikhookeanskaya st., Khabarovsk, Russia \\ ${ }^{4}$ National Research Tomsk State University, 63405036 Lenin ave., Tomsk, Russia \\ ${ }^{5}$ Samara State University of Economics, 443090141 Soviet Army st., Samara, Russia
}

\begin{abstract}
To assess the impact of sustainable development on social wellbeing, it is necessary to emphasize its objective and subjective factors. The complex of objective factors of well-being of modern society, in all sectors of which highly productive production of tangible and intangible goods dominates, is organically connected with the innovative development of environmentally-friendly technologies, the international diffusion of innovations in the field of "green economy". Accordingly, the objective factors of well-being in the system of sustainable development include, firstly, reproductive ones, such as the availability of new technologies of the "green economy" and the frequency of their replacement, the productivity of resource-saving industries, the inter-sectoral expansion of the replacement of non-renewable resources, and government support for environmental entrepreneurship. Secondly, here we include the prevailing mechanisms of factor distribution and redistribution of income - the formation of natural and intellectual rents, the pricing of natural resources and the return on investment in the production of the "green economy". Finally, thirdly, the important objective factors of social well-being in the system of sustainable development are those institutional norms that determine both production and environmental processes in the national economy. The complex result of these processes development is the environmental well-being.
\end{abstract}

\section{Introduction}

The main subjective factors of well-being, perceived individually, are the result of the impact of objective factors on society as a whole and on individuals in particular. They form personal values, such as:

\footnotetext{
* Corresponding author: ksa.skst@kuzstu.ru
} 
- personal property status (income, housing, access to medical services, education, etc.); - environmental conditions (health, human security), socialization (participation in environmental protection activities, social status and public role of environmental activists, entrepreneurs implementing technologies of the "green economy");

- emotional conditions (personal development, respect, mental health, stress level, beliefs, etc.);

- professional implementation (competencies, productivity, satisfaction with the profession, etc.).

\section{Materials and Methods}

The combination of well-being factors determines the ecological and economic profile of well-being, which changes in accordance with the progressive change in the stages of industrial and technological development (H. Udzawa [1], D. Bell [2], K. Clark [3], R. Reich [4]).

According to D. Bell, a breakthrough in the industrial development of Western countries and Japan in the XX century. was associated with a massive cross-sectoral relocation of capital and labor from the secondary sector of the economy (manufacturing industries that dominated the first third of the 20th century) to the tertiary (transport, travel, communications - the second third of the 20th century), and then - quaternary sector (global trade and finance - the last third of the 20th century). Since the beginning of the XXI century. in economically developed countries, the dominance of a new post-industrial (the fifth) sector is expected (medicine, software, design services, education, consulting, global information business). As a result, by the middle of the century, an increase in the environmental well-being of technologically advanced countries is expected to be significantly higher than the level of the beginning of the 21 st century.

In accordance with the three-sector model of the national economy of C. Clark, throughout the XX century. in the industrialized countries of a market economy, there was a shift in economic activity from the primary sector, which dominated in the 19th century (mining, construction and agriculture), to the secondary (deep processing of raw materials, modern transport, communications and finance). Thus, today we are witnessing a transition to the tertiary sector (high-tech and innovative industries, including developed production of intangible goods). According to C. Clark, these processes in one way or another affect both technologically developed and developing countries, but occur in them asynchronously. For the Russian economy, this means that the presence of industrial competitiveness by world standards in the raw materials sector cannot become an exceptional factor in increasing environmental well-being.

In a five-sector model of the economy, R. Reich singled out material (from the first to third sectors) and intangible (fourth and fifth sectors) production. During the XX century. there was an accumulation and accelerated reproduction of knowledge and human capital. This determined the forthcoming transfer of most productive forces from material to intangible production. This process is accompanied by deep structural changes in the employment sector and activates new mechanisms for the development of the "green economy".

It can be assumed that the technological backwardness of the Russian economy reflects a particular case of an unfair income distribution and a wealth gap between the raw material elite on the one hand and society as a whole on the other. According to a modern interpretation of the methodology of Wilfredo Pareto [5-6], in an industrialized economy since the end of the first quarter of the XX century. there is an inverse relationship between the income distributed among households and the number of 
participants in this process: $80 \%$ of GDP is distributed among $20 \%$ of citizens, and the remaining $20 \%$ of GDP is distributed among $80 \%$ of the population (Pareto ratio "80/20") [7-8]. According to some economists, in the Russian economy since the early 1990s this ratio was in the range 90/10 [9-10]. This corresponds to the provisions of Max Weber's theory of political capitalism [11], according to which the vast majority of federal and regional business elites in Russia were created either by the state (through contacts with its representatives), or as a result of its patronage for a certain group of businessmen.

Applying the Pareto optimum (any change that does no harm to anyone and brings some kind of subjectively assessed benefit is an improvement) to the current situation in the distribution of income in the Russian economy, we can draw the following conclusions.

The reason for the negative gap in the environmental aspect of industrial development between Russia and countries with developed market economies can be presented in accordance with the provisions of the post-industrial theory of D. Bell, C. Clark, R. Reich as the weakness or absence of individual sectors of the economy with modern technologies. Accordingly, in the theory of technological layers, Russia's technological lag appears as a result of the completion of processing of raw materials at the level of intermediate products in most sectors of the economy.

In Russia, the influence of objective factors of social and environmental well-being is restrained by the low level of technologies used and weak institutional norms that are typical of a natural resource-rental economy. As a result, the subjective factors of environmental well-being are also many times underestimated in comparison with technologically developed countries. In this case, the situation is quite stable, since significant technological changes can lead to such a structural transformation of the economy, in which the well-being of the most influential social groups is reduced. In this model of the distribution of factors of production and income, the state, intervening in the Russian economy, trying to increase the raw elite, helps to maintain technological and environmental backwardness, rather than accelerating the development of the "green economy".

The action of objective factors of social well-being in the Russian economy does not allow providing access to the modern level of technologically developed countries in which the "green economy" is gaining strength. The reason for this lies in the deindustrial development trend, which has been entrenched since the beginning of market transformations in the 1990s and continues to this day. This trend reflects negative structural changes in the economy and is manifested in a reduction in the share of the industrial sector in Russia's GDP as a whole (from 1993-2017 from 47 to 35\%), and in the gross output of industry - compression of the manufacturing sector from 72 to $61 \%$ (by value added) [12]. In this regard, the proportion of the population employed in industry and counting on the income level corresponding to the modern developed industrial society for the period 1993-2017 fell from 43 to $28 \%$ [13].

The expansion of the industrial sector in the Russian economy is constrained by low labor productivity (in 2017, 3 times lower than the United States and 2.6 times lower than the European Union) and is aggravated by a critical level of physical depreciation of fixed capital ( $49 \%$, and in some sectors of the manufacturing industry up to $80 \%$ ) [14]. This happens against the background of the dependence of three quarters of enterprises on the supply of imported equipment and components, and one third on the borrowing of foreign technologies.

The concentration of income from the extraction and export of raw materials in Russia is extremely high and corresponds to the autocratic and oligarchic regimes in Latin America and the Middle East. 
Consequently, the prospects for increasing social and environmental well-being in the Russian economy are inextricably linked with neo-industrially induced economic growth. At the same time, a departure is necessary both from the dominance of the redistribution of natural and administrative rents, and from the prevailing model of investing in industrial modernization, the latter being implemented by the state mainly in favor of mining corporations. It is in this that the prospects for humanization and greening economic growth in the Russian economy are laid.

\section{Results and Discussion}

Neo-industrial greening of the Russian economy is the most promising form of humanization of economic growth. It carries positive structural changes in employment and the factor distribution of income due to the transformation of the reproductive and sectoral structure of the national economy. For the growth of the green economy and the transition to a sustainable positive trend of social and environmental well-being, profound structural changes are needed. They must be initiated in the reproductive system, have a modernization nature and an ecologically oriented character. It is in this way that the action of objective factors of social and environmental well-being can be activated. As a result, a new Pareto optimum and consensus of interests of recipients of factor incomes will be achieved. The key factor of production in the process of neoindustrialization of the economy is intellectual capital. He actively participates in the environmental modernization of basic industries during the inter-sectoral transfer of innovations, radically changing the structure of employment and income.

Promising forms of environmentally-oriented neo-industrialization of the Russian economy are as follows:

1. Formation of network clusters of information technologies that are not "tied" to the parent companies - large IT developers. These clusters can become sources of innovation for industry, creating technologies for processing and redistributing information, which is an important element of modern production chains. The complex of modern network technologies demanded by the Russian market is quite diverse. The most common ones include: creating web-based database interfaces and access to equipment (from home to industrial); distributed ("cloud") programming - the generation of complex computer programs that individual specialists are capable of creating "in parts"; professional internet consulting; distance online training and online marketing, etc.

2. Development of production capacities for the deep processing of hydrocarbons, production of the latest composite and multifunctional synthetic materials, smelting of the latest heavy-duty alloys. Modernization of these industries in the basic sectors of the Russian economy is necessary to provide high-tech industries with the latest materials - carbon fiber, reinforced plastics, nano-lubricating and adsorption materials, organometallic compounds, the latest semiconductors and organosilicon compounds, heavy-duty plastics, etc. World market prices for them exceed the cost raw materials several hundred and even thousands of times. In this regard, their production can create jobs with the highest level of wages in modern industry. Industries in which employment should take on a neo-industrial character combine convergent technologies. This is realized by combining similar processes of various industries and initiating inter-sectoral cooperation. They include the synthesis of technologies and the production of metal and polymer processing, the production of industrial robots, spacecrafts, the merger of biochemistry and energy, etc.

3. Improving the energy efficiency of industries traditional for the Russian economy heat and power producing, housing, design and production of new electric generators 
and engines, building materials.

4. The genesis of "green energy" - the transition to renewable energy sources. This means the development of the production of solar cells, high-capacity batteries, small hydro and wind energy in existing energy enterprises.

The most expected results of the transition to a policy of accelerated neoindustrialization are the growth of medium and high-tech employment. It is inspired by the revival of manufacturing and the growth of its international competitiveness. The demand for its products should be presented primarily by the basic branches of Russian industry. For them, the transition to a new material and technological base is the basis of technological modernization.

The investment source for financing the innovative modernization of the Russian processing complex may be the investment of state corporations and state-owend banks. It is at least impractical to count on innovatively effective state investments in enterprises and companies fully or partially controlled by the state in the fields of mechanical engineering, radio electronics, instrument making, and the production of modern materials. The investment basis of neo-industrialization can be represented in the form of manufacturing and high-tech public-private partnerships, public-private banking consortia.

Neo-industrial innovative modernization of industry, based on an inter-sectoral technology transfer, cannot be carried out without the participation of the Russian economy in the international diffusion of innovations. In this regard, an important objective factor in increasing social well-being during neo-industrial development is the expansion of technological cooperation between Russian and foreign companies leaders in the raw materials and manufacturing sectors, as well as companies in industries that are actively forming a convergent-technological basis for innovative modernization. Preserving the scientific and intellectual potential of Russian industry requires accelerating the processes of scientific and industrial integration within the framework of inter-cluster interactions at the national and international levels.

In turn, expanding the participation of the Russian economy in the international diffusion of innovations requires the formation of appropriate institutions for the interaction of science, business and the state. They should be based on a single technological platform for neo-industrial development, norms and rules for the transfer of innovations from the defense industry to civilian sectors, mechanisms for intercluster and network interaction of raw materials, manufacturing, and high-tech enterprises.

\section{Conclusion}

Neo-industrial development is in many ways a non-alternative way out of the Russian economy from the trend of de-ecologization and the transition to a sustainable development. At the same time, innovative modernization as its key driver with a characteristic increase in national competitiveness and the "integration" of the Russian economy into the global chains of production of modern high-tech goods should not replace the main goal of economic development - increasing social welfare of the population. In other words, the revival of modern industry should not occur in isolation from the formation of new social groups, which in essence correspond to the modern stage of scientific and technological progress. Overcoming the de-elitization of research and engineering activities, environmental entrepreneurship, rooted in the de-industrial conditions of Russian market reforms, requires a coordinated implementation of the investment, innovation, industrial and social policies of the state. In it, special attention should be paid to the reproduction of human capital at a new level - environmental well- 
being.

\section{References}

1. I. Ekeland, K. Temam, Convex analysis and variational problems (North Hollan, Amsterdam, 1976)

2. D. Bell, The coming of post-industrial society. Venture in social forecasting (Collman Pub. New York, 1973)

3. C. Clark, The conditions of economic progress (Logan Pub., London, 1991)

4. R. Reich, The work of nations. Preparing ourselves for 21 st Century capitalism (Univ. of N.Y. Pub., New York, 1992)

5. V. Pareto, The Rise and Fall of Elites: An Application of Theoretical Sociology (Transaction Publishers Los Angeles, 1991)

6. V. Pareto, The Transformation of Democracy. Transaction Books (Jolley, Hannover, 1984)

7. E. Dotsenko, N. Ezdina, E3S Web Conf., 41, 04048 (2018)

8. E. Dotsenko, N. Ezdina, S. Mudrova, E3S Web Conf., 41, 04050 (2018)

9. O. Kalenov, S. Kukushkin, R. Kamanina, E3S Web Conf., 105, 04028 (2019)

10. S. Kukushkin, O. Kalenov, E3S Web Conf., 105, 04022 (2019)

11. M. Weber, Wirtschaft und Gesellschaft (Goldberg: Berlin, 1925)

12. S. K. Demchenko, J. Y. Suslova, V. V. Kaplun, O. S. Demchenko, Journal of Internet Banking and Commerce, 21:S3 (2016)

13. T. Skryl, E. Shavina, E. Dotsenko, E3S Web Conf., 105, 04049 (2019)

14. A. Balabanova, V. Balabanov, E. Dotsenko, N. Ezdina, E3S Web Conf., 15, 04013 (2017) 